\title{
Check ID Cards with an Excel Function
}

\author{
Xianyu Meng ${ }^{1, a, *}$, Yanping $\mathrm{Cui}^{1}$ and Xiaoyan $\mathrm{Cai}^{1}$ \\ ${ }^{I}$ Army Engineering University Ordnance Sergeant School, Wuhan, Hubei, China \\ a849934279@qq.com \\ *Corresponding author
}

\section{ABSTRACT}

This paper introduces the rules for the preparation of CHINA's ID number, and elaborates the method of checking the ID number using functionin in Excel, and elaborates on the function used.

Keywords: excel, ID number, function

\section{INTRODUCTION}

In various forms that contain personnel information, the ID number is a very important data.This article details the use of Excel function to verify the ID number method, has a strong practical value.

The number of China's resident ID card is compiled in accordance with national standards, consisting of 18 digits, in order from left to right in order: 6 digits of digital address code, 8 The number of digital birth dates, 3-digit sequence codes, and 1-digit check codes. In the id card number preparation rules, the last one is to play the role of verification. The check rule is to take out the first 17 digits of the ID card number, multiply by the corresponding weighting factor and sum s, using S Divide by 11 for the remainder Y,and then get the ID number 18 by comparison check code corresponding table Bits. The verification method is about to calculate the check code and the original ID number of the 18th digit comparison, consistent is through verification, otherwise the ID number is wrong. Through such preliminary verification can effectively avoid input errors, and even identify some of the forged identity cards. The whole process is complex, with an Excel table instance being implemented step-by-step. Figure 1 is a soldier information sheet containing the ID number, which needs to be checked.

\begin{tabular}{|c|c|c|c|c|c|c|c|c|c|c|c|c|}
\hline \\
\hline \multicolumn{13}{|c|}{ 士兵信息 } \\
\hline 证件号 & 娃名 & 性别 & 身份证号 & 身份证号校验 & \begin{tabular}{|l|} 
出生日期 \\
\end{tabular} & 年㱓 & 籍贯 & 入伍时间 & 单位 & 发证机关 & 任职时间 & 职务/军衡 \\
\hline 1000001 & 柏军 & 女 & 130629198704040563 & TRUE & $1987 / 4 / 4$ & 28 & 浙江建伟 & $2007 / 12 / 1$ & 96521部队60分队 & 96521部队司令部 & 2008.1 & 司机，一级士官 \\
\hline 1000002 & 吕文武 & 男 & 411123198810039615 & FALSE & $1988 / 10 / 3$ & 26 & 四川成才 & $2005 / 12 / 1$ & 96521部队61分队 & 96521 部队司令部 & 2006.4 & 同机、一级士官 \\
\hline 1000003 & 李恒昌 & 男 & 320104198208312499 & FALSE & $1982 / 8 / 31$ & 33 & 山东荷泽 & $2001 / 12 / 1$ & 96521部队78分队 & 96521部队司令部 & 2003. 3 & 电话员、一级士官 \\
\hline 1000004 & 韩赤峰 & 男 & 350822198705174116 & FALSE & $1987 / 5 / 17$ & 28 & 浙江安吉 & $2008 / 12 / 1$ & 96521部队83分队 & 96521部队司令部 & 2008.5 & 卫生员、上等兵 \\
\hline 1000005 & 张勇 & 男 & 320902198607 & TRUE & $1986 / 7 / 9$ & 29 & 湖北武汉 & $2006 / 12 / 1$ & 队 & 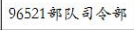 & 2007.1 & 同机、上等兵 \\
\hline 1000006 & 王海军 & 男 & 320323198604140218 & UE & $1986 / 4 / 14$ & 29 & 广西都州 & $2005 / 12 / 1$ & 521 部队89 & 96521 部队司令部 & 2007.4 & 司机、二级士官 \\
\hline 1000007 & 薛州 & 男 & 422827198302150733 & FALSE & $1983 / 2 / 15$ & 32 & 河北唐山 & $2006 / 12 / 1$ & 21 部阳 & 96521 部队司令部 & 108.3 & 班长、一级士官 \\
\hline 1000008 & 陈文丽 & 咨 & 513723198609170047 & FALSE & $1986 / 9 / 17$ & 28 & 辽宁沈阳 & $2008 / 12 / 1$ & 96521部队83分队 & 96521 部队司令部 & 2008.5 & 颀生员、列兵 \\
\hline
\end{tabular}

Figure 1 A sheet need to be checked

\section{HOW TO CHECK}

\subsection{Weighted Sum}

The first thing you need to extract is the first 17 digits of your ID number, which can be done with the MID function: MID(text, start num, num chars): Returns characters of a specified length from the starting position specified in the text string.
Numbers extracted from the MID function require weighted sum (the weighted number is shown in Figure 4), and the expression can be written as:

$=\mathrm{MID}(\mathrm{D} 3,1,1) * 7+\mathrm{MID}(\mathrm{D} 3,2,1) * 9+\mathrm{MID}(\mathrm{D} 3,3,1) * 10+\mathrm{MID}($ $\mathrm{D} 3,4,1) * 5+\mathrm{MID}(\mathrm{D} 3,5,1) * 8+\mathrm{MID}(\mathrm{D} 3,6,1) * 4+\mathrm{MID}(\mathrm{D} 3,7,1) *$ $2+\mathrm{MID}(\mathrm{D} 3,8,1) * 1+\mathrm{MID}(\mathrm{D} 3,9,1) * 6+\mathrm{MID}(\mathrm{D} 3,10,1) * 3+\mathrm{MID}$ $(\mathrm{D} 3,11,1) * 7+\mathrm{MID}(\mathrm{D} 3,12,1) * 9+\mathrm{MID}(\mathrm{D} 3,13,1) * 10+\mathrm{MID}(\mathrm{D} 3$, $14,1) * 5+\operatorname{MID}(\mathrm{D} 3,15,1) * 8+\mathrm{MID}(\mathrm{D} 3,16,1) * 4+\mathrm{MID}(\mathrm{D} 3,17,1)$ $* 2$

Enter the expression in the "Id number verification" cell, which is E3 cell. The result is shown in Figure 2.

\begin{tabular}{|c|c|c|c|c|c|c|c|c|c|c|}
\hline D & $\varepsilon$ & $F$ & ${ }_{6}$ & H & 1 & j & $\mathrm{z}$ & 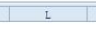 & $x$ & 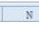 \\
\hline \multicolumn{11}{|c|}{ 士兵信息 } \\
\hline 身份证号 & 身份证号校验 & 出生日期 & 年龄 & 籍贯 & 入伍时间 & 单位 & 发证机关 & 任职时间 & 职务/军衔 & \\
\hline 130629198704040563 & 284 & $\mid 1987 / 4 / 4$ & 28 & 浙江建德 & $2007 / 12 / 1$ & 96521部队60分队 & 96521部队司令部 & 2008.1 & 司机、一级士官 & \\
\hline
\end{tabular}

Figure 2 The result of weighted sum

\subsection{Finding the Remainder}

Finding the remainder in Excel can be realized by MOD function:
MOD(number, divisor): Returns the remainder of the division of two numbers. The positive and negative sign of the result is the same as the divisor.

The summation result of the first step is nested in the MOD function as a parameter, and the expression is as follows: 
$=\operatorname{MOD}(\operatorname{MID}(\mathrm{D} 3,1,1) * 7+\mathrm{MID}(\mathrm{D} 3,2,1) * 9+\mathrm{MID}(\mathrm{D} 3,3,1) * 10+$ $\operatorname{MID}(\mathrm{D} 3,4,1) * 5+\mathrm{MID}(\mathrm{D} 3,5,1) * 8+\mathrm{MID}(\mathrm{D} 3,6,1) * 4+\mathrm{MID}(\mathrm{D} 3$, $7,1) * 2+\operatorname{MID}(\mathrm{D} 3,8,1) * 1+\mathrm{MID}(\mathrm{D} 3,9,1) * 6+\mathrm{MID}(\mathrm{D} 3,10,1) * 3+$ $\operatorname{MID}(\mathrm{D} 3,11,1) * 7+\mathrm{MID}(\mathrm{D} 3,12,1) * 9+\mathrm{MID}(\mathrm{D} 3,13,1) * 10+\mathrm{MI}$

\begin{tabular}{|c|c|c|c|c|c|c|c|c|c|}
\hline \multirow{2}{*}{\multicolumn{10}{|c|}{ 士兵信息 }} \\
\hline & & & & & & & & & \\
\hline 身份证号 & 身份证号校验 & 出生日期 & 年龄 & 籍贯 & 入伍时间 & 单位 & 发证机关 & 任职时间 & 职务/军衔 \\
\hline 130629198704040563 & 9 & $1987 / 4 / 4$ & 28 & 浙江建德 & $2007 / 12 / 1$ & 96521部队60分队 & 96521部队司令部 & 2008.1 & 司机、一级士官 \\
\hline
\end{tabular}

Figure 3 The result of remainder

\subsection{Finding the Check Code}

After calculating the remainder, we need to query the

\begin{tabular}{|c|c|c|c|c|c|c|c|c|c|}
\hline \multicolumn{2}{|c|}{ After calculating the } & $\Delta$ & A & B & C & D & \multirow{2}{*}{$\begin{array}{c}E \\
\text { 校验码 }\end{array}$} & \multirow{2}{*}{$\mathrm{F}$} & \multirow[t]{2}{*}{ G } \\
\hline & & 1 & 身份证位数 & 加权数 & & 余数 & & & \\
\hline & & 2 & 1 & 7 & & 0 & 1 & & \\
\hline & & 3 & 2 & 9 & & 1 & 0 & & \\
\hline & & 4 & 3 & 10 & & 2 & $\mathrm{X}$ & & \\
\hline & & 5 & 4 & 5 & & 3 & 9 & & \\
\hline & & 6 & 5 & 8 & & 4 & 8 & & \\
\hline & & 7 & 6 & 4 & & 5 & 7 & & \\
\hline & & 8 & 7 & 2 & & 6 & 6 & & \\
\hline & & 9 & 8 & 1 & & 7 & 5 & & \\
\hline & & 10 & 9 & 6 & & 8 & 4 & & \\
\hline & & 11 & 10 & 3 & & 9 & 3 & & \\
\hline & & 12 & 11 & 7 & & 10 & 2 & & \\
\hline & & 13 & 12 & 9 & & & & & \\
\hline & & 14 & 13 & 10 & & & & & \\
\hline & & 15 & 14 & 5 & & & & & \\
\hline & & 16 & 15 & 8 & & & & & \\
\hline & & 17 & 16 & 4 & & & & & \\
\hline & & 18 & 17 & 2 & & & & & \\
\hline
\end{tabular}

$\mathrm{D}(\mathrm{D} 3,14,1) * 5+\mathrm{MID}(\mathrm{D} 3,15,1) * 8+\mathrm{MID}(\mathrm{D} 3,16,1) * 4+\mathrm{MID}(\mathrm{D} 3$, $17,1)^{*} 2,11$ )

The result is shown in Figure 3.

Figure 4 Check data

The function, whitch is named "VLOOKUP",can be used to find check codes according to the remainder in this worksheet.

VLOOKUP(lookup_value, table_array, col_index_num, [range_lookup]): You can use the VLOOKUP function to search for a cell area (region: two or more cells on a worksheet). Cells in a region can be adjacent or not. The first column then returns the values in any cell on the same row in the region.

According to the rules of function usage, the first parameter in this example can determine the remainder returned by the previous step. The search area is the D2 to E12 regions of the "Check Data" worksheet. The reference method can be expressed as follows:

\begin{tabular}{|c|c|c|c|c|c|c|c|c|c|}
\hline \multicolumn{10}{|c|}{ 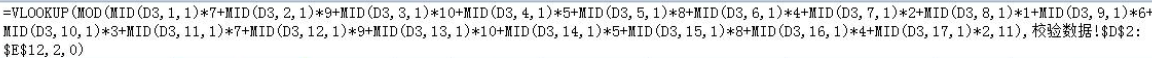 } \\
\hline$D$ & 8 & 8 & 6 & H & 1 & 2 & $\mathrm{R}$ & 1 & $x$ \\
\hline \multicolumn{10}{|c|}{ 士兵信息 } \\
\hline 身份证号 & 身份证号校验 & 出生日期 & 年龄 & 籍贯 & 入伍时间 & 单位 & 发证机关 & 任职时间 & 职务/军衔 \\
\hline 130629198704040563 & 3 & $1987 / 4 / 4$ & 28 & 浙江建德 & $2007 / 12 / 1$ & 96521部队60分队 & 96521部队司令部 & 2008.1 & 司机、一级士官 \\
\hline
\end{tabular}

Figure 5 The result of function

\subsection{Comparison Verification}

The final step requires the check code to be compared with the 18th digit of the ID number to check that it is consistent. The ability to check for consistency can be implemented using the EXACT function: corresponding check codes, and make the corresponding relationship between the remainder and the check codes into a table and store it in another worksheet. The worksheet is named "Check Data", as shown in Figure 4.
The third parameter is to find the column where the region target is located. In this case, it is 2 . The last parameter logic value means whether to enable Fuzzy Lookup or not. In this case, no need to enable, just fill in " 0 " or "FALSE". Therefore, the synthesis expression is:

$=$ VLOOKUP $($ MOD $(\operatorname{MID}(\mathrm{D} 3,1,1) * 7+\mathrm{MID}(\mathrm{D} 3,2,1) * 9+\mathrm{MID}($ $\mathrm{D} 3,3,1) * 10+\mathrm{MID}(\mathrm{D} 3,4,1) * 5+\mathrm{MID}(\mathrm{D} 3,5,1) * 8+\mathrm{MID}(\mathrm{D} 3,6,1)$ $* 4+\mathrm{MID}(\mathrm{D} 3,7,1) * 2+\mathrm{MID}(\mathrm{D} 3,8,1) * 1+\mathrm{MID}(\mathrm{D} 3,9,1) * 6+\mathrm{MID}$ $(\mathrm{D} 3,10,1) * 3+\mathrm{MID}(\mathrm{D} 3,11,1) * 7+\mathrm{MID}(\mathrm{D} 3,12,1) * 9+\mathrm{MID}(\mathrm{D} 3,1$ $3,1) * 10+\operatorname{MID}(\mathrm{D} 3,14,1) * 5+\mathrm{MID}(\mathrm{D} 3,15,1) * 8+\mathrm{MID}(\mathrm{D} 3,16,1)$ $* 4+\mathrm{MID}(\mathrm{D} 3,17,1) * 2,11)$, Check Data!\$D\$2:\$E\$12,2,0) The function returns the result as shown in Figure 5. 
$\mathrm{D}(\mathrm{D} 3,12,1) * 9+\mathrm{MID}(\mathrm{D} 3,13,1) * 10+\mathrm{MID}(\mathrm{D} 3,14,1) * 5+\mathrm{MID}(\mathrm{D}$ $3,15,1) * 8+\operatorname{MID}(\mathrm{D} 3,16,1) * 4+\operatorname{MID}(\mathrm{D} 3,17,1) * 2,11), \quad$ Check Data!\$D\$2:\$E\$12,2,0))

The result is shown in Figure 6.
$=\mathrm{EXACT}(\mathrm{MID}(\mathrm{D} 3,18,1), \mathrm{VLOOKUP}(\mathrm{MOD}(\mathrm{MID}(\mathrm{D} 3,1,1) * 7$ $+\mathrm{MID}(\mathrm{D} 3,2,1) * 9+\mathrm{MID}(\mathrm{D} 3,3,1) * 10+\mathrm{MID}(\mathrm{D} 3,4,1) * 5+\mathrm{MID}($ $\mathrm{D} 3,5,1) * 8+\mathrm{MID}(\mathrm{D} 3,6,1) * 4+\mathrm{MID}(\mathrm{D} 3,7,1) * 2+\mathrm{MID}(\mathrm{D} 3,8,1) *$ $1+\mathrm{MID}(\mathrm{D} 3,9,1) * 6+\mathrm{MID}(\mathrm{D} 3,10,1) * 3+\mathrm{MID}(\mathrm{D} 3,11,1) * 7+\mathrm{MI}$

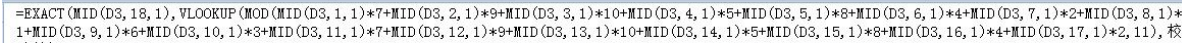
敛数据! \$D\$2:\$®\$12,2,

士兵信息

\begin{tabular}{|c|c|c|c|c|c|c|c|c|c|}
\hline 身份证号 & 身份证号校验 & 出生日期 & 年龄 & 籍贯 & 入伍时间 & 单位 & 发证机关 & 任职时间 & 职务/军衔 \\
\hline 130629198704040563 & TRUE & $\mid 1987 / 4 / 4$ & 28 & 浙江建德 & $2007 / 12 / 1$ & 96521 部队60分队 & 96521部队司令部 & 2008.1 & 司机、一级士官 \\
\hline 41112 & FALSE & $1988 / 10 / 3$ & 26 & 四川成才 & $05 / 12 / 1$ & 521部队61分队 & 521部队司令部 & 006.4 & 同机、一级士官 \\
\hline 32010 & FALSE & $82 / 8 / 31$ & 33 & $=$ & 11 & 以 & 部 & 03.3 & 电话员、一级士官 \\
\hline 3508 & ALSE & 政 & 28 & & & 队 & 部 & 5 & 卫生员 \\
\hline 32090 & & & 29 & & & 队 & 部 & 0.1 & . \\
\hline 3203231 & & 14 & $2=$ & 厂西䂙州 & $2 / 1$ & 队 & - 部 & 007.4 & 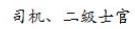 \\
\hline 422827 & FALSE & 15 & 32 & 河北唐山 & $/ 1$ & 以 & 部 & 08.3 & 㚫士官 \\
\hline 37231 & LSE & $6 / 9 / 17$ & 2 & 辽宁沈門 & $2 / 1$ & 96521部际 & 96521部队司令部 & 2008.5 & 卫里员、列兵 \\
\hline
\end{tabular}

Figure 6 The last result of check

The result shows that the ID number has passed the verification if it is "TRUE", else the ID number has errors.

\section{CONCLUSION}

Identity cards are very important to everyone. Whether the authentication is successful or not, the channels of identification card numbers are usually charged, such as bank channels and Ministry of Public Security channels. Before sending validation to these channels, validating them first can improve the success rate of charging validation and save cost. It can also improve the user experience, feedback in time when users input errors without waiting for the return of validation channel results. Relying on Excel software, this paper mainly uses Excel function to realize the verification function. It is easy to operate and difficult to realize. I hope it can inspire everyone's work and study.

\section{REFERENCES}

[1] Xiao Yunting, "Computer Application Foundation", Beijing: Machinery Industry Press.

[2] Li Jibing. "Excel Formula and Function Application Example”, Beijing: China Youth Publishing House. 